\title{
CHICKEN GERMPLASMS AND THEIR CONSERVATION IN BANGLADESH: A REVIEW
}

\author{
M.A. Hamid* \\ School of Agriculture and Rural Development, Bangladesh Open University \\ Gazipur-1705, Bangladesh
}

\begin{abstract}
The present article addresses the scenario of chicken genetic resources, their production and reproduction performances and their conservation in Bangladesh. The chickens, among other poultry species available in the country, are the most versatile component for meat and egg production. The chicken germplasms available in the country are indigenous, exotic, crossbred, and commercial hybrid. The indigenous chicken population is comprised of Non-descript Desi (ND), Naked Neck (NN), Aseel (AS), Hilly $(\mathrm{H})$, Native Dwarf and Jungle Fowl etc. The exotic chicken such as, White Leghorn (WL), White Rock (WR), White Cornish (WC), Rhode Island Red (RIR), Australorp, Fayoumi, Barred Plymouth Rock (BPR) etc. are imported mostly to upgrade the indigenous stock. The crossbred of different chickens are used in the country in intensive, semi-intensive and scavenging management system. The commercial hybrid such as grandparent stock (GP), parent stock (PS), commercial broiler, commercial layer etc. has got most popularity for meat and egg production in the country. Conservation and improvement program of endangered native chicken such as Aseel and Native Dwarf chicken should be taken both in-situ or ex-situ in vivo by public sector/research institutes/universities.
\end{abstract}

Keywords: Bangladesh, Chicken, Germplasm, Conservation

\section{INTRODUCTION}

Bangladesh has a long history of chicken rearing under traditional backyard farming. Since 1990, commercial chicken farming started on small scales. Presently the industry is being accomplished the capacity to fulfill almost the domestic demand for broiler meat and layer eggs. Bangladesh is rich in respect of chicken germplasms. Different types of chicken such as indigenous chicken, exotic and crossbred chicken, and commercial hybrid are available in the country.

This sub-sector is an important avenue in fostering agricultural growth and reduces malnutrition for the people in Bangladesh. Development of chicken has generated

\footnotetext{
*Corresponding author: hamidethu@yahoo.com
} 
considerable employment through the production and marketing of chicken and chicken products in Bangladesh. It is an integral part of farming system in Bangladesh and has created direct, indirect employment opportunity including support services for about 6 million people (Ansarey, 2012; Da Silva and Rankin, 2014). It has proved as an attractive economic activity, thereby, indicating its importance for the entire economy. It accounts for $14 \%$ of the total value of livestock output and is growing rapidly (Raihan and Mahmud, 2008). Chicken meat alone contributes $37 \%$ of the total meat production in Bangladesh. Chicken contributes about 22 to $27 \%$ of the total animal protein supply in the country (Prabakaran, 2003). In Asia, chicken manure is used as feed for fish where chicken are raised on top of the ponds as part of an integrated system, for example, fish-cum- chicken farming (FAO, 2014).

In the public sector, the present number of chicken farms and hatcheries are 31 and 6 , respectively (DLS, 2015). The objective for establishing of those farms was to produce, conserve and develop chicken genetic resources. There are 9 grandparent stock farms in Bangladesh and supplies about $80 \%$ of the total demand of parent stock; the rest $20 \%$ is imported (BPD, 2019). In October 2011, there were 82 parent stock farms and hatcheries in operation in Bangladesh and producing 55-60 lac day old broiler and 5 lac day old layer chicks per week.

In the recent year, attention has been given to improvement and conservation of native chickens due to higher preference of consumers for native chicken and higher price of native chicken than the exotic, crossbred and commercial hybrids. Among the native chicken, Non-descript Deshi, Nacked Neck and Hilly are not endangered and they don't need to be conserved. The Aseel and the Native Dwarf are endangered breed and variety of native chicken and need to be conserved.

The present article addresses the available chicken genetic resources with their distributions, productive and reproductive performances along with conservation status of endangered breed/variety so the chicken producers and researchers can get all the information for future improvement and conservation program of chicken.

\section{Geographic distribution of different genotypes of chicken}

The distribution pattern of chicken is very interesting in the country. The Nondescript Deshi chickens are distributed throughout the country except in some hilly areas of the country. Normal neck and Naked Neck indigenous birds are found in different regions of the country though the distribution of Naked Neck bird is comparatively very thin. The Aseel is a rare variety found only in some areas of Brahmanbria district. The Hilly birds are found in the hilly areas of Chittagong region. Jungle fowl as the name implies is found in the forest of Hill Tracts, Sundarbans and also found in the Madhupur and Rajendrapur forest areas. The breed/types of chicken, their geographic distribution and utility are presented in Table 1. 
Table 1. Geographic distribution and utility of chicken in Bangladesh

\begin{tabular}{|c|c|c|c|}
\hline Breed /Type & Geographic distribution & Agro-ecological Zone & Utility \\
\hline $\begin{array}{l}\text { Non-descript } \\
\text { Deshi }\end{array}$ & $\begin{array}{l}\text { Throughout the country except } \\
\text { Chittagong Hill districts }\end{array}$ & $\begin{array}{l}\text { All agro- ecological } \\
\text { zones except } \\
\text { Chittagong Hill } \\
\text { districts }\end{array}$ & $\begin{array}{l}\text { Egg and meat } \\
\text { production }\end{array}$ \\
\hline Naked Neck & Throughout the country & $\begin{array}{l}\text { All agro- ecological } \\
\text { zones }\end{array}$ & $\begin{array}{l}\text { Egg and meat } \\
\text { production }\end{array}$ \\
\hline Aseel & Brahmanbaria district & $\begin{array}{l}\text { Middle Meghna flood } \\
\text { plain }\end{array}$ & $\begin{array}{l}\text { Game and } \\
\text { recreation }\end{array}$ \\
\hline Hilly & Chittagong Hill districts & Chittagong Hill tracts & $\begin{array}{l}\text { Egg and meat } \\
\text { production }\end{array}$ \\
\hline Native Dwarf & $\begin{array}{l}\text { Sporadically available in the } \\
\text { country }\end{array}$ & - & $\begin{array}{l}\text { Egg and meat } \\
\text { production }\end{array}$ \\
\hline Jungle Fowl & $\begin{array}{l}\text { In forest of Chittagong, } \\
\text { Chittagong Hill Tracts, } \\
\text { Sundarbans, Madhupur, Sylhet }\end{array}$ & $\begin{array}{l}\text { Chittagong coastal } \\
\text { plain, Old Brahmaputra } \\
\text { flood plain areas }\end{array}$ & Meat \\
\hline Fayoumi & All over the country & $\begin{array}{l}\text { All agro- ecological } \\
\text { zones }\end{array}$ & Egg production \\
\hline RIR & In Govt. farms & - & For crossbreeding \\
\hline WL & In Govt. farms & - & $\begin{array}{l}\text { Egg production } \\
\text { and } \\
\text { crossbreeding }\end{array}$ \\
\hline WR & In Govt. farms & - & For crossbreeding \\
\hline BPR & In Govt. farms & - & For crossbreeding \\
\hline $\begin{array}{l}\text { Sonali (RIR } \\
\text { Fayoumi) }\end{array}$ & All over the country & $\begin{array}{l}\text { All agro- ecological } \\
\text { zones }\end{array}$ & Meat production \\
\hline $\begin{array}{l}\text { Rupali (WL } \\
\text { Fayoumi) }\end{array}$ & All over the country & $\begin{array}{l}\text { All agro- ecological } \\
\text { zones }\end{array}$ & Egg production \\
\hline $\begin{array}{l}\text { Broiler GPS and } \\
\text { PS }\end{array}$ & $\begin{array}{l}\text { Mainly Chittagong, Kishoregonj, } \\
\text { Thakurgaon, Panchogor, } \\
\text { Chuadanga, Gazipur district }\end{array}$ & $\begin{array}{l}\text { All agro- ecological } \\
\text { zones }\end{array}$ & $\begin{array}{l}\text { Commercial } \\
\text { broiler chick } \\
\text { production }\end{array}$ \\
\hline $\begin{array}{l}\text { Layer GPS and } \\
\text { PS }\end{array}$ & $\begin{array}{l}\text { Mainly Chittagong, Kishoregonj, } \\
\text { Thakurgaon, Panchogor, } \\
\text { Chuadanga district }\end{array}$ & $\begin{array}{l}\text { All agro- ecological } \\
\text { zones }\end{array}$ & $\begin{array}{l}\text { Commercial layer } \\
\text { chick production }\end{array}$ \\
\hline $\begin{array}{l}\text { Commercial } \\
\text { broiler hybrids }\end{array}$ & All over the country & $\begin{array}{l}\text { All agro- ecological } \\
\text { zones }\end{array}$ & $\begin{array}{l}\text { Commercial meat } \\
\text { production }\end{array}$ \\
\hline $\begin{array}{l}\text { Commercial } \\
\text { layer hybrids }\end{array}$ & All over the country & $\begin{array}{l}\text { All agro- ecological } \\
\text { zones }\end{array}$ & $\begin{array}{l}\text { Commercial egg } \\
\text { production }\end{array}$ \\
\hline
\end{tabular}

Source: FAnGRBD, BLRI, 2015; BPD, 2019

$[\mathrm{RIR}=$ Rhode Island Red, WL $=$ White Leghorn, WR $=$ White Rock, BPR = Barred Plymouth Rock; GPS = Grand Parent Stock, PS = Parent Stock] 


\section{Available chicken germplasms in Bangladesh}

The chicken germplasms of Bangladesh is composed of indigenous or native type, exotic type, crossbred type and commercial hybrid which have been described as below -

\section{A) Indigenous chicken}

The indigenous chicken population is comprised of a number of breeds/types such as Non-descript Desi (ND), Naked Neck (NN), Aseel (AS), Hilly (H), Native Dwarf, Jungle Fowl and Frizzled Plumage (Bhuiyan et al., 2005; Das et al., 2008) in respect of the morphological variations as well as production performances. Non-descript native colored chicken as an important source of meat and eggs are more acceptable to all classes of people (Barua and Howlider, 1990). Blood protein variants study revealed that Non-descript Deshi, Naked Neck, Hilly and Native Dwarf they may be regarded as one breed or population because of having small distances among them (Okada et al., 1988). The indigenous chickens of Bangladesh do not fall into any recognized breed. It is assumed that the present Deshi (indigenous) chicken was originated from Gallus gallus (Faruque et al., 1987). The body measurements of different types of indigenous chicken are presented in Table 2.

Table 2. Body measurements of different adult native chicken

\begin{tabular}{l|l|l|l|c|c}
\hline \multicolumn{1}{c}{ Parameter } & \multicolumn{1}{c}{$\begin{array}{c}\text { Non-descript } \\
\text { Deshi }\end{array}$} & \multicolumn{1}{c}{ Naked Neck } & Aseel & Hilly & Jungle fowl \\
\hline $\begin{array}{l}\text { Mature body } \\
\text { weight (g) }\end{array}$ & $1114 \pm 266$ & $969 \pm 150$ & $3166 \pm 457$ & $1585 \pm 422$ & $961 \pm 150$ \\
Body depth (cm) & $12.88 \pm 1.81^{1,2}$ & $12.64 \pm 0.39^{1,2}$ & $20.90 \pm 2.19^{1,2}$ & $7.44 \pm 0.16^{1,2}$ & $11.84 \pm 0.41^{1}$ \\
Shank length & $7.6 \pm 0.94^{1}$ & $7.18 \pm 0.75^{1,2}$ & $14.60 \pm 1.14^{1,2}$ & $9.95 \pm 1.15^{1,2}$ & $6.67 \pm 0.82^{1}$ \\
$(\mathrm{~cm})$ & $7.60 \pm 0.40^{2}$ & & & & \\
Trunk length & $22.25 \pm 2.88^{1}$ & $20.09 \pm 0.83^{1}$ & $33.80 \pm 1.92^{1,2}$ & $21.5 \pm 2.41^{1}$ & $21.67 \pm 0.82^{1}$ \\
$(\mathrm{~cm})$ & $22.30 \pm 2.88^{2}$ & $10.09 \pm 0.83^{2}$ & & $21.50 \pm 2.40^{2}$ & \\
Wing length (cm) & $17.70 \pm 2.13^{1,2}$ & $16.09 \pm 1.04^{1}$ & $34.80 \pm 4.21^{1,2}$ & $33.39 \pm 3.73^{1,2}$ & $15.0 \pm 1.55^{1}$ \\
& & $16.69 \pm 1.04^{2}$ & & & \\
\hline
\end{tabular}

Source: Uddin et al., 2011 ${ }^{1}$; Bhuiyan et al., 2005²

\section{i. Non-descript Deshi}

The Non-descript Deshi chicken is more acceptable to rural people as an important source of meat and eggs due to lower nutritional demand and higher resistance to diseases and heat stress (Barua and Howlider, 1990). They are long adapted to local climate, reared under low inputs system, and have low productivity, but produce tasty meat and egg. The morphological characteristics of indigenous Deshi chicken are presented in Table 3 . 
Table 3. Morphological characteristics of Indigenous chicken ex situ

\begin{tabular}{|c|c|}
\hline Trait & Description \\
\hline Plumage colour & $\begin{array}{l}\text { Reddish black (33.13\%), Blackish red }(13.5 \%) \text {, Red }(13.7 \%) \text {, Black } \\
(12.67 \%) \text {, White with black spot }(11.04 \%) \text {, Reddish white }(0.61 \%) \text {, } \\
\text { Brown (4.9), Blackish white }(4.9 \%) \text {, Mixed }(5.55 \%)\end{array}$ \\
\hline Shank colour & Yellow (37.22\%), White (39.87\%), Black (20.04\%) \\
\hline Eye colour & Black $(99 \%)$ \\
\hline Ear lobe colour & Red (25.97\%), Reddish white (44.79\%) \\
\hline Comb colour & Bright red $(59 \%)$ and pale $((41 \%)$ \\
\hline Skin colour & White $(92.22 \%), \operatorname{Red}(7.78 \%)$ \\
\hline Egg shell colour & Light brown (67\%) and white (27\%) \\
\hline Feather pattern & No definite (61\%) and lacing (17\%) \\
\hline Body size & Medium (70\%) large (19\%) small (11\%) \\
\hline Comb type & $\begin{array}{l}\text { Single }(96.12 \%) \text {, Single (cape headed) }(3.84 \%) \text {, Rose }(0.02 \%) \text {, Butter } \\
(0.02 \%)\end{array}$ \\
\hline Spur & Rudimentary (98\%) \\
\hline Egg size & Medium $(80 \%)$ \\
\hline
\end{tabular}

Source: Sarker et al., 2014; Bhuiyan et al., 2005

\section{ii. Naked Neck}

The Naked Neck chickens are special type within Non-descriptive Deshi chicken adapted to scavenging system and are available all over the country. The mixed colour of feathers is common and red, black or reddish yellow are predominant all over the body. Featherless red skin on neck and yellow skin on legs are the most typical characteristics of these chickens. They are more resistant to diseases than the exotic chickens. They are used for meat and egg production and also efficient producer of high quality and high priced meat. The morphological characteristics of Naked Neck chicken are presented in Table 4.

Table 4. Morphological characteristics of Naked Neck and Hilly chicken

\begin{tabular}{lll}
\hline \multicolumn{1}{c|}{ Trait } & \multicolumn{1}{c}{ Naked neck } & \multicolumn{1}{c}{ Hilly } \\
\hline Plumage colour & Black or reddish & Grey or reddish \\
Skin colour & Yellow & Yellow \\
Shanks & Featherless & Featherless \\
Egg shell colour & Brownish & Brownish \\
\hline
\end{tabular}

Source: Bhuiyan et al., 2005 
iii. Aseel

Aseel is found in Brahmanbaria district and some cities like Dhaka, Chittagong and Sylhet. They are known as game bird used for fighting and recreation. The morphological characteristics of Aseel chicken are presented in Table 5.

Table 5. Morphological characteristics of Aseel chicken

\begin{tabular}{ll}
\hline \multicolumn{1}{c}{ Trait } & \multicolumn{1}{c}{ Description } \\
\hline Shank colour & Yellowish (100\%) \\
Shank feathering & No feathering (100\%) \\
Wattles & Medium size (22.81\%), Rudimentary (77.19\%) \\
Beak color & Yellow (100\%) \\
Eye colour & Yellowish (100\%) \\
Ear lobe colour & Red (100\%) \\
Ear lobe shape & Small (75.40\%), Medium (24.60\%) \\
Comb type & Pea comb (75.95\%), Strawberry comb (24.05\%) \\
Skin colour & Whitish (100\%) \\
Egg shell colour & Light brown (77.78\%), White (22.22\%) \\
Spur & Large spurs (98\%) \\
\hline
\end{tabular}

Source: Sarker et al., 2012

\section{iv. Hilly}

The Native chickens of Chittagong Hill districts are called Hilly chicken. The Hilly chickens are also adapted to scavenging system and are available in the southeastern hilly districts of the country. They are bigger in size than the native chicken and round in shape covered with feathers of different colours. The legs are featherless with yellow skin. They are more resistant to diseases than the exotic chicken. The shell colour of egg is light brown and they have the brooding habit. They are used for meat and egg production. The morphological characteristics of Hilly chicken are presented in Table 4.

\section{v. Native Dwarf}

Native Dwarf is usually found sporadically in the country. They are long adapted with special genetic merit of low input requirement. They are used for meat and egg production. The morphological characteristics of Native Dwarf chicken are presented in Table 6. 
Table 6. Morphological characteristics of indigenous dwarf chicken

\begin{tabular}{l|l}
\hline \multicolumn{1}{c}{ Trait } & \multicolumn{1}{c}{ Description } \\
\hline Plumage colour & $\begin{array}{l}\text { Black (41.11\%), Blackish red (12.22\%), Reddish black (12.22\%), } \\
\text { Golden (11.11\%), Blackish golden (17.78\%) and Black with white } \\
\text { spot (5.56\%) }\end{array}$ \\
Shank colour & $\begin{array}{l}\text { Black (27.78\%), Slate (23.33\%), Yellow (22.22\%), Yellowish } \\
(16.67 \%) \text { and White (10.00\%) }\end{array}$ \\
Eye colour & Black (100\%) \\
Ear lobe colour & Red (40.00\%), White (15.56\%) and Reddish white (44.44\%) \\
Beak color & Black (33.33\%), White (22.22\%) and Yellow (44.44\%) \\
Comb colour & Bright red (66.67\%) and Reddish (33.33\%) \\
Skin colour & White (90.00\%) and Yellow (10.00\%) \\
Egg shell colour & Light brown (76.56\%) and white (23.44\%) \\
Comb type & Mainly single (97\%) \\
\hline
\end{tabular}

Source: Ferdaus et al., 2016

vi. Jungle Fowl

Jungle Fowl usually found in the forest of Chittagong, Chittagong Hill Tracts, Sundarbans, Madhupur and Sylhet.

\section{B) Exotic chicken and their crosses}

The exotic chicken such as, White Leghorn (WL), White Rock (WR), White Cornish (WC), Rhode Island Red (RIR), Australorp, Fayoumi, Barred Plymouth Rock (BPR) are imported mostly to upgrade the indigenous stock. Fayoumi is extensively used in rural areas and well adapted under farm condition in Bangladesh (Anisuzzaman, 1988). This breed is originated from Egypt and possesses the characteristics of early sexual maturity, more egg production and low mortality (Barua et al. 1998). Some research reports supported that crossing of Fayoumi with exotic breed increased egg production, egg size and body weight. Ali (1989) also found that crossing of Fayoumi with other standard exotic breed improved egg size, growth rate and adaptability of crossbreds under farm condition of Bangladesh.

The crossbred of different chicken such as Deshi $\times$ WL, Deshi $\times$ WC, Deshi $\times$ RIR, Deshi $\times$ Fayoumi, WL $\times$ Fayoumi, RIR $\times$ Fayoumi, Aseel $\times$ Australorp, RIR $\times$ Naked Neck, WL $\times$ Naked Neck are used in the country in intensive, semiintensive and scavenging management system. The Department of Livestock Services (DLS) of Bangladesh has introduced Sonali crossbred chicken (by crossing RIR males with Fayoumi females) to improve rural poultry production. They are very much suited to the semi intensive rearing system in rural areas. They have better production records and higher disease resistance (Miah et al., 2002). The Sonali have 
the highest egg production, lowest mortality and highest profit per hen among eight crossbred chickens tested under rural condition of Bangladesh (Rahman et al., 1997).

\section{C) Commercial hybrid}

There are many commercial hybrid such as grandparent stock (GP), parent stock (PS), commercial broiler, commercial layer etc. are available in the country. The grandparent stock is imported and the country relies on importation of this stock. Currently there are 9 grandparent stock farms such as Aftab G.P. Farms Limited, C.P. (Bangladesh) Co. Ltd., Kasila (Bangladesh) Limited, Kazi Grand Parents Limited, M.M. Agha G.P. Farms Limited, Nourish Grand Parents Limited, Paragon G.P. Limited and Rashik G.P. Hatchery Limited are in the country (BPD, 2019, Hamid et al., 2017). The available GP chicks are Cobb 500, Hubbard Classic, Lohman Meat, Novogen Brown etc (BPD, 2019).

The Parent Stock chicken such as Lohmann Brown Classic, Lohmann White, Lohmann Indian River, Isa Brown, Isa White, Shaver Star Cross 579 Brown, Shaver White, Shaver Black, Hisex Brown, Hisex White, Bovan's Brown, Bovan's White, Bovan's Goldline, Bovan's Nera, Dekalb Gold, Dekalb White, Dekalb Black, Sasso Coloured, Hubbard Classic, Novogen Brown, Novogen White, Hubbard HI-Y Flex, Colored Broiler, Arbor Acres Plus S, Arbor Acres Plus, Lohman Meat, Nick chick, Brown Nick, Super Nick etc. are reared and marketed by 14 Parents Farms in the country (Hamid et al., 2017; BPD, 2019).

The commercial broiler, such as Cobb, Hubbard Classic, Starbro, Ross, Arbor Acres, Vancobb etc. are reared by different large, medium and small commercial broiler farms in the country (BPD, 2019).

The commercial layer, such as B.V. 300, Isha Brown, Isha White, Lohmann Brown, Lohmann White, Hisex Brown, Hisex White, Starcross-579, Hy-line etc. are reared by different large, medium and small commercial layer farms in the country (BPD, 2019).

\section{Production and reproduction performances of chicken in Bangladesh}

\section{A) Performances of indigenous chicken}

The production and reproduction performances of Non-descript Deshi, Naked Neck, Aseel, Hilly, Native Dwarf and Jungle Fowl chicken are summarized in Table 7, 8, 9, 10,11 and 12 respectively. 
Table 7. Production and reproduction performances of Non-descript Deshi chicken

\begin{tabular}{ll}
\multicolumn{1}{c}{ Trait } & \multicolumn{1}{c}{ Average } \\
\hline Day old chicks weight $(\mathrm{g})$ & $26-32^{1}, 30.39 \pm 0.44^{2}$ \\
Adult female live weight $(\mathrm{g})$ & $1600-1700^{1}, 1500^{3}, 1000-1300^{4}$ \\
Adult male live weight $(\mathrm{g})$ & $2000-2500^{1}$ \\
Egg production/hen/year & $150-155^{1}, 35-45^{5}, 50-60^{3}, 45-50^{4}$ \\
Egg weight @ onset of lay (g) & $29-33^{1}$ \\
Egg weight (g) & $43-45^{1}, 35-40^{3} 35-39^{5}$ \\
Fertility (\%) & $94.86 \pm 1.38^{1}, 88.60 \pm 2.03^{2}, 85.7 \pm 1.0^{6}$ \\
Hatchability (\%) & $84.29 \pm 2.10^{1}, 83.04 \pm 1.82^{2}, 84-87^{5}, 89.0 \pm 1.0^{6}$, \\
& $73.28 \pm 1.29^{7}$ \\
Mature live weight (g) & $1141.48^{5}, 1100^{3}, 1212.2 \pm 6.6^{6}, 805.46 \pm 8.60^{7}$ \\
Age at point of lay (d) & $190-200^{5}$ \\
Length of laying (d) & $10-16^{5,3}$ \\
No. of eggs/clutch & $10-16^{5,3}$ \\
No. of clutch/ year & $3-4^{5,3}$ \\
No. of eggs/set/clutch & $10-15^{5,3}$ \\
Brooding age (d) & $49^{5,3}$ \\
Age at sexual maturity (d) & $145^{5,3}$ \\
Feed intake (g/d) & $83^{5,3}$ \\
\hline
\end{tabular}

Source: BLRI, 2017¹ Faruque et al., 2017²; BLRI, 2004³ ; Rahman and Salah Uddin, 2017 ; Bhuiyan et al., $2005^{5}$; Faruque et al., 2015; Jahan et al., $2017^{7}$

Table 8. Production and reproduction performances of Naked Neck chicken

\begin{tabular}{l|l}
\hline \multicolumn{1}{c}{ Trait } & \multicolumn{1}{c}{ Average } \\
\hline Day old chicks weight $(\mathrm{g})$ & \multicolumn{1}{c}{$27-34^{1}, 29.61 \pm 0.53^{2}$} \\
Adult female live weight $(\mathrm{g})$ & $1300-1500^{1}, 1170^{3}, 1171^{4}$ \\
Adult male live weight $(\mathrm{g})$ & $1500-2000^{1}$ \\
Egg production/hen/year & $170-180^{1}, 50-55^{3}, 90-120^{5}$ \\
Egg weight @ onset of lay (g) & $27-30^{1}$ \\
Egg weight (g) & $42-44^{1}, 37-40^{5}, 42^{3}$ \\
Fertility (\%) & $88.09 \pm 2.11^{1}, 81.93 \pm 2.69^{2}, 85.4 \pm 1.4^{6}$ \\
Hatchability (\%) & $68.99 \pm 1.49^{1}, 80.47 \pm 2.38^{2}, 77.5 \pm 1.4^{6}, 76.67 \pm 4.22^{7}$ \\
Age at sexual maturity (m) & $6.5 \pm 1.46^{3}, 6.5 \pm 1.5^{5}$ \\
Weight at sexual maturity (g) & $969 \pm 132^{3}, 1149^{5}, 1180.7 \pm 9.3^{6}, 782.85 \pm 31.56^{7}$ \\
& \\
\hline
\end{tabular}

Source: BLRI, 2017 ; Faruque et al., 2017²; Bhuiyan et al., 2005³ Rahman and Salah Uddin, 2017 BLRI, 2004 ; Faruque et al., 2015 ; Jahan et al., $2017^{7}$ 
Table 9. Production and reproduction performances of Aseel chicken

\begin{tabular}{ll}
\hline \multicolumn{1}{c}{ Trait } & \multicolumn{1}{c}{ Average } \\
\hline Adult live weight male $(\mathrm{g})$ & $3,749.12 \pm 83.44$ \\
Adult live weight female $(\mathrm{g})$ & $2,062.50 \pm 105.26$ \\
Age at first lay $(\mathrm{w})$ & $28.86 \pm 1.40$ \\
Number of clutch per year & $3.36 \pm 0.17$ \\
Number of eggs per clutch & $10.71 \pm 0.26$ \\
Total number of eggs per year & $35.71 \pm 1.68$ \\
Egg weight $(\mathrm{g})$ & $40.69 \pm 0.82$ \\
Hatchability $(\%)$ & $71.68 \pm 9.59$ \\
\hline
\end{tabular}

Source: Sarker et al., 2012

Table 10. Production and reproduction performances of Hilly chicken

\begin{tabular}{|c|c|}
\hline Trait & Average \\
\hline Day old chicks weight $(\mathrm{g})$ & $26-30^{1}, 32.73 \pm 0.60^{2}$ \\
\hline Adult female live weight $(\mathrm{g})$ & $1800-2000^{1}, 1900^{3}$ \\
\hline Adult male live weight $(\mathrm{g})$ & $2500-3000^{1}$ \\
\hline Egg production/hen/year & $130-140^{1}, 80-100^{3}$ \\
\hline Egg weight @ onset of lay (g) & $28-30^{1}$ \\
\hline Egg weight $(g)$ & $43-45^{1}, 40-42^{3}$ \\
\hline Fertility $(\%)$ & $88.40 \pm 2.31^{1}, 84.73 \pm 2.72^{2}, 85.2 \pm 1.4^{5}$ \\
\hline Hatchability (\%) & $80.26 \pm 2.50^{1}, 75.55 \pm 2.43^{2} 85.6 \pm 1.4^{5}$ \\
\hline Age at sexual maturity $(\mathrm{d})$ & $150^{3}$ \\
\hline Weight at sexual maturity (g) & $1326^{3}, 1499.0 \mathrm{a} \pm 9.5^{5}$ \\
\hline \multicolumn{2}{|c|}{ 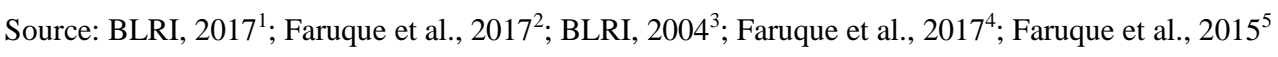 } \\
\hline Trait & Average \\
\hline Age at sexual maturity $(\mathrm{m})$ & $195^{1}, 166.53 \pm 0.93^{2}$ \\
\hline Egg weight (g) & $39^{1}, 38.25 \pm 0.12^{2}$ \\
\hline Adult body weight $(\mathrm{kg})$ & $1.2-1.6^{1}$ \\
\hline Egg number per year & $121^{1}$ \\
\hline Feed intake $(\mathrm{g} / \mathrm{d})$ & $80^{1}$ \\
\hline
\end{tabular}

Source: BLRI, 2004 ${ }^{1}$; Ferdaus et al., $2016^{2}$ 
Table 12. Production and reproduction performances of Jungle Fowl

\begin{tabular}{l|c}
\hline \multicolumn{1}{c|}{ Trait } & Average \\
\hline Age at sexual maturity $(\mathrm{m})$ & $5.9 \pm 0.42$ \\
Weight at sexual maturity $(\mathrm{g})$ & $961 \pm 150$ \\
Adult body weight $(\mathrm{kg})$ & 3.20 \\
Egg production $(\%)$ & 14.07 \\
\hline
\end{tabular}

Source: BLRI, 2004

\section{B) Performances of exotic and crossbred chicken}

The production and reproduction performances of exotic and crossbred chicken are summarized in Table 13.

Table 13. Production and reproduction performances of exotic and crossbred chicken

\begin{tabular}{|c|c|c|c|c|c|}
\hline \multirow[t]{2}{*}{ Economic Trait } & \multicolumn{5}{|c|}{ Name of chicken } \\
\hline & RIR & WL & WC & Fayoumi & Sonali \\
\hline DOC weight $(\mathrm{g})$ & $33.8 \pm 1.34^{1}$ & - & - & $32.6 \pm 1.06^{1}$ & $33.8 \pm 1.86^{1}$ \\
\hline Growth rate $(\mathrm{g} / \mathrm{d})$ & $13.8 \pm 0.10^{1}$ & - & - & $11.7 \pm 0.04^{1}$ & $13.7 \pm 0.10^{1}$ \\
\hline Death rate $(\%)$ & $2.82 \pm 0.15^{1}$ & - & - & $1.68 \pm 0.20^{1}$ & $3.82 \pm 0.15^{1}$ \\
\hline Fertility (\%) & $\begin{array}{l}89.5 \pm 2.65^{1} \\
87.88^{2}\end{array}$ & $79.86^{2}$ & $69.0^{2}$ & $\begin{array}{l}91.2 \pm 0.64^{1} \\
79.17^{2}\end{array}$ & $91.2 \pm 0.30^{1}$ \\
\hline Hatchability (\%) & $\begin{array}{l}83.1 \pm 1.66^{1} \\
66.12^{2}\end{array}$ & $76.41^{2}$ & $71.0^{2}$ & $\begin{array}{l}82.9 \pm 0.40^{1} \\
68.34^{2}\end{array}$ & $83.3 \pm 1.41^{1}$ \\
\hline $\begin{array}{l}\text { Age at first laying } \\
\text { (wk) }\end{array}$ & $19.1 \pm 0.33^{1}$ & - & - & $22.4 \pm 0.20^{1}$ & $21.1 \pm 0.61^{1}$ \\
\hline Egg weight (g) & $47.58^{2}$ & $54.44^{2}$ & $59.0^{2}$ & $43.29^{2}$ & - \\
\hline
\end{tabular}

Source: Dutta et al., 2012 ${ }^{1}$; Khan and Bhuiyan, $2001^{2}$

\section{C) Performances of commercial chicken}

The production and reproduction performances of some commercial layer of Aftab Hatchery Limited, Bhagalpur, Bajitpur, Kishoregonj, Bangladesh are summarized in Table 14. The production and reproduction performances of Novogen Brown and Bovan's Brown layer of Dimond Chicks Limited, Baridhara DOHS, Dhaka, Bangladesh are summarized in Table 15. The production and reproduction performances of Shaver Brown of Nahar Agro Limited, South Khulshi, Chattagram, Bangladesh are summarized in Table 16. The production and reproduction performances of Isa Brown of Bay Agro Industries Limited, Kawran Bazar, Dhaka, Bangladesh are summarized in Table 17. 
Table 14. Production and reproduction performances of commercial layer chicken

\begin{tabular}{l|l|l|l}
\hline \multirow{2}{*}{ Trait } & \multicolumn{3}{c}{ Average } \\
\cline { 2 - 4 } & Novogen Brown & \multicolumn{1}{c}{ Isa Brown } & Novogen White \\
\hline Live ability (\%) & $94-96$ & $94-96$ & $93-95$ \\
Feed intake @ 1-18 wks (kg) & $6.84-7.02$ & $6.17-6.32$ & $6.07-6.23$ \\
Highest egg production (\%) & 95 & 95. & 95 \\
Egg weight (g) & 66.6 & 64.8 & 66.4 \\
$\begin{array}{l}\text { Daily feed intake @ production } \\
\text { period (kg) }\end{array}$ & $115-120$ & $115-120$ & $106-110$ \\
$\begin{array}{l}\text { Body weight @ end of egg } \\
\text { production (kg) }\end{array}$ & 2.1 & & \\
\hline
\end{tabular}

Source: Based on Aftab Hatchery Limited Farm Report

Table 15. Production and reproduction performances of Novogen Brown and Bovan's Brown layer

\begin{tabular}{l|c|c}
\hline \multirow{2}{*}{ Trait } & \multicolumn{2}{c}{ Average } \\
\cline { 2 - 3 } & Novogen Brown & Bovan's Brown \\
\hline Live ability (\%) & $97-98$ & 98 \\
Highest egg production (\%) & 98 & 98 \\
Egg weight (g) & $63-64$ & $63-64$ \\
Feed intake @ 1-17 wks (kg) & 6 & 6 \\
Daily feed intake @ production period (kg) & $113-115$ & 113 \\
Body weight @ 90 wks of age (g) & 1920 & 1975 \\
Production period (wks) & $18-90$ & $18-110$ \\
Hen housed egg production (no.) & $406-415$ & 500 \\
\hline
\end{tabular}

Source: Based on Dimond Chicks Limited Farm Report

Table 16. Production and reproduction performances of Shaver Brown layer

\begin{tabular}{l|c}
\hline \multicolumn{1}{c|}{ Trait } & Average \\
\hline Live ability (\%) & 94.2 \\
Highest egg production (\%) & 95 \\
Egg weight (g) & 63.2 \\
FCR & 2.22 \\
Daily feed intake @ production period (kg) & 114 \\
Body weight @ 80 wks of age (kg) & 2 \\
Production period (wks) & $18-80$ \\
\hline
\end{tabular}

Source: Based on Nahar Agro Limited Farm Report 
Table 17. Production and reproduction performances of Isa Brown layer

\begin{tabular}{lc}
\multicolumn{1}{c|}{ Trait } & Average \\
\hline Live ability @ 18-90 wks (\%) & 93.2 \\
Highest egg production (\%) & 96 \\
Egg weight (g) & 62 \\
Daily feed intake @ production period (kg) & 110 \\
Body weight @ 90 wks of age (g) & 2015 \\
Hen housed egg production (no.) & 409 \\
\hline
\end{tabular}

Source: Based on Bay Agro Industries Limited Farm Report

\section{Conservation of Chicken Genetic Resources}

According to the number of bird available in the country, some varieties of the native chicken such as, Non-descript Deshi, Nacked Neck and Hilly are not endangered and they don't need to be conserved. The number of Aseel Aseel and the Native Dwarf are low and so endangered. These two type of chickens need to be conserved. It is important for economic, social and cultural reasons. There are two means of conservation i.e. in situ and ex situ. Conserving the live animals that exist in nature is in situ conservation. The animals are maintained in their original habitats under native conditions with no interference in their mode of management, feeding and other conditions. The main problem of in situ conservation is inbreeding and genetic drift typical of small populations. The ex situ conservation is to be used when the endangered population is dismally low in numbers, as this process has its own innate problems. It may suffer from spread of disease, or neglect during periods of institutional weakness, besides being costly in long term preservations and losing the relatedness of current genotype with environment when one of these is preserved for long time.

The importance of conservation between and within breed genetic diversity is widely recognized. Irreversible loss of breeds, or genetic variation within breeds, is undesirable. The FAOs Global Plan of Action on AnGR (FAO, 2007), as well as the Convention on Biological Diversity and national policies all addresses the importance of conservation and sustainable use of animal genetic resources. These international agreements formed the basis for national policies related to the conservation and management of FAnGR through in situ or ex situ conservation strategies. Presently the project research for the conservation of Aseel chicken is ongoing in Bangladesh Agricultural University and Hazi Danesh Science and Technology University with the joint research of Japan. On the other hand, the project research for the conservation of Native Dwarf is ongoing in Department of Livestock Services and Bangladesh Livestock Research Institute. 


\section{CONCLUSION}

From the above discussion, it may be concluded that Bangladesh is rich in chicken genetic resources. These serve well in fulfill nutritional requirement of the country and income generation for millions of people. There is scope to improve the productivity of Indigenous chicken through appropriate breeding and husbandry practice. Aseel and Native Dwarf need immediate attention for conservation and improvement.

This study represents useful resources for future study that may be threatened to the existence of local varieties, especially Aseel and Native Dwarf. This two endangered varieties, Aseel and Native Dwarf need immediate attention for conservation

\section{REFERENCES}

Ali, I. (1989). Reproductive performances of Fayoumi, Rhode Island Red and Fayoumi X Rhode Island Red crossbred hens and subsequent growth rate of their offspring up to sexual maturity. M. Sc. Thesis. Department of Poultry Science, Bangladesh Agricultural University, Mymensingh.

Anisuzzaman, M. (1988). A study on growth rate, feed efficiency and livability of Fayoumi chicken under Bangladesh condition. M. Sc. Thesis. Department of Poultry Science, Bangladesh Agricultural University, Mymensingh.

Ansarey, F.H. (2012). Prospects of poultry industry in Bangladesh. Proceedings of the Seminar and Reception on Animal Husbandry Education and Profession in Bangladesh- A Journey of 50 Years, (AHEPB'12), Dhaka, Bangladesh. pp: 62-65

Barua, A., and Howlider, M.A.R. (1990). Prospect of native chicken in Bangladesh. Poultry Adviser, 23: 57-61.

Barua, A., Howlider, M.A.R., and Yoshimura, Y. (1998). A study on the performance of Fayoumi, Rhode Island Red and Fayoumi X Rhode Island Red chickens under rural condition of Bangladesh. Asian Australasian Journal of Animal Science, Vol. 11(6): 635-641.

Bhuiyan, A.K.F.H., Bhuiyan, M.S.A., and Deb, G.K. (2005). Indigenous chicken genetic resources in Bangladesh: current status and future outlook. Animal Genetic Resources Information, 36: 73-84.

BLRI. (2015). Bangladesh Livestock Research Institute. Farm Animal Genetic Resource in Bangladesh. Annual Report on Livestock, Division of Livestock Statistics, Bangladesh Livestock Research Institute, Savar, Dhaka, Bangladesh.

BLRI. (2004). Bangladesh Livestock Research Institute. First Report on Animal Genetic Resources of Bangladesh, Bangladesh Livestock Research Institute, Government of Bangladesh, Dhaka, Bangladesh. p. 42.

Bangladesh Poultry Directory. (2019). Published by Golam Mostafa Rob, $19^{\text {th }}$ Edition, March 2019, Dhaka, Bangladesh.

Das, S.C., Chowdhury, S.D., Khatun, M.A. Nishibori, M. Isobe, N., and Yoshimura, Y. (2008). Poultry production profile and expected future projection in Bangladesh. World's Poultry Science Journal, 64: 99-118. 
Da Silva, C.A., and Rankin, M. (2014). Contract Farming for Inclusive Market Access. Food and Agriculture Organization of the United Nations, Rome, Italy, ISBN: ISBN 978-925-108061-0, Pages: 227.

DLS. (2015). Annual report on livestock. Division of Livestock Statistics, Ministry of Fisheries and Livestock, Farmgate, Dhaka, Bangladesh.

Dolberg, F. (2008). Bangladesh poultry sector country review. FAO animal production and health division, emergency centre for Transboundary Animal Disease, socioeconomics, production \& biodiversity unit, FAO, Rome, Italy.

Dutta, R.K., Islam, M.S., and Kabir, M.A. (2012). Assessment of the production performance and economic efficiencies of available chicken breeds (Gallus domesticus L.) in Rajshahi, Bangladesh, University Journal of Zoology, Rajshahi University, 31: 13-18.

FAO. (2007). Global Plan of Action for Animal Genetic Resources, Food and Agriculture Organization of the United Nations (FAO), Rome, Italy, 2007.

FAO. (2014). Decision tools for family poultry development. FAO Animal Production and Health Guidelines No. 16, FAO., Rome, Italy. http://www.fao.org/docrep/019/i3542e/ i3542e.pdf.

Faruque, S., Bhuiyan, A.K.F.H., Ali, M.Y., Joy, Z.F., and Rashid, M.A. (2017). Conservation and improvement of native chicken: performance of fourth generation. Asian Australasian Journal of Bioscience and Biotechnology, 2 (1): 37-44.

Faruque, S., Islam, M.N., and Bhuiyan, A.K.F.H. (2015). Ex situ Improvement of Indigenous Chicken in Bangladesh. Tropical Agricultural Research Vol. 26 (4): 596 - 607.

Faruque, M.O., Hasnath, M.A., Mostafa, K.G., Okada, I., Amano, T., Kurosawa, Y., Ita K., and Nsmikawa. T. (1987). Conservation of Livestock genetic resources in Bangladesh Past, Present and Future. P 119- 137. In Amano T., ed., Genetic Studies on Breed Differentiation of the Native Domestic Animals of Bangladesh. Hiroshima University, Japan.

Ferdaus, A.J.M, Bhuiyan, M.S.A., Hassin, B.M., Bhuiyan, A.K.F.H., and Howlider. M.A.R. (2016). Phenotypic characterization and productive potentialities of indigenous dwarf chicken of Bangladesh. Bangladesh Journal of Animal Science, 45 (1): 52-61.

Hamid, M.A., Ahmed, S., Rahman, M.A., and Hossain, K.M. (2017). Status of Poultry Industry in Bangladesh and the Role of Private Sector for its Development. Asian Journal of Poultry Science, 11 (1): 1-13.

Jahan, S., Islam, F., Bhuiyan M.S.A. and Bhuiyan. A.K.F.H. (2017). Productive and reproductive performances of indigenous chicken in the rural condition of Bangladesh. Bangladesh Journal of Animal Science, 46 (2): 121-127.

Khan, A.K. and Bhuiyan, A.K.F.H. (2001). Estimation of heterosis for some economic traits in chicken. Progressive Agriculture, 12 (1 and 2): 145-150.

Miah, M.S., Islam, M.A., and Ali, M.A. (2002). Growth and egg production performance of exotic pure breed and crossbreeds chicken. The Bangladesh Veterinarian, 19 (1): 43-47.

Okada, I., Maeda, Y., Hashiguchi, T., Hasnath, M.A., Faruque M.O., and Majid. M.A. (1988). Gene constitution of indigenous chicken in Bangladesh. Japanese Poultry Science, 25(1): 15-26. 
Prabakaran, R. (2003). Good practices in planning and management of integrated commercial poultry production in South Asia. FAO Animal Production and Health Paper 159, Food and Agriculture Organization of the United nations, Rome, Italy.

Rahman, M., Sorensen, P., Jensen H.A., and Dolberg. F. (1997). Exotic hens under semi scavenging conditions in Bangladesh. Livestock research for Rural Development. 9 (3): $1-11$.

Rahman, S., and Salahuddin A.B.M. (2017). Backyard Poultry Production System in Bangladesh. P 39-58. In Siddiky, N.A., edi., Backyard Poultry Production Systems in SAARC Member States. SAARC-Agriculture Centre, Dhaka. 1215.

Raihan, S. and Mahmud, N. (2008). Trade and poverty linkages: A case study of the poultry industry in Bangladesh. Cuts Citee Working Paper No. 6. http://www.cutscitee.org/pdf/wp08-06.pdf.

Sarker, N. R., Hoque, A., Faruque, S., Islam N., and Bhuiyan. A.F.H. (2014). An ex situ study on body characteristics and effect of plumage color on body weight of indigenous chicken (Gallus domesticus) in Bangladesh, Acta Scientiarum Animal Sciences, 36 (1): 79-84.

Sarker, M.J.A., Bhuiyan, M.S.A., Faruque, M.O., Ali, M.A. and Lee, J.H. (2012). Phenotypic Characterization of Aseel Chicken of Bangladesh. Korean Journal of Poultry Science, 39 (1): 9-15.

Uddin, M.H., Ali, A., Akter Y., and Khatun. M.A. (2011). Geographical distribution, classification, characterization and conservation of different native chicken varieties of Bangladesh. Bangladesh Research Publications Journal, 5 (3): 227-233. 